\title{
Improving Efficiency of Asset Management in the Context of Ensuring Competitiveness of Mechanical Engineering Enterprises in Developing Countries
}

\author{
Irina M. Yepifanova*
}

Odessa National Polytechnic University, Department of Economics of Enterprises, Odessa, Ukraine

\begin{abstract}
The research paper deals with the formation of new scientific solutions regarding increasing the efficiency of asset management in the context of ensuring the competitiveness of mechanical engineering enterprises in developing countries. The study noted the disparity in the development of economically developed and developing countries. It is revealed that one of the main aspects of such disparity is the competitiveness of both the economies of the countries as a whole, and of individual industries and enterprises. At the same time, the importance of ensuring the competitiveness of mechanical engineering enterprises in developing countries was noted, taking into account their potential and opportunities for stimulating GDP and employment growth in these countries. The relationship between the competitiveness of mechanical engineering enterprises and their asset management is established. The main problems of asset management at the mechanical engineering enterprises in the developing countries are localized, and the ways of their elimination are proposed taking into account the division of enterprises into those operating as part of the transnational and foreign corporations, large enterprises with national capital, medium and small enterprises with national capital. A considerable range of problems regarding the asset management in small and medium enterprises was noted. Directions of further scientific researchers are suggested.
\end{abstract}

Keywords: Competitiveness, Developing countries, Mechanical engineering, Enterprise, Asset management.

\section{INTRODUCTION}

The acceleration of the globalization processes in the world raises questions about the development of countries that build their economic systems. The political and economic pressure of the developed countries, the growing influence on the economy of transnational corporations, internal financial and economic problems lead to the loss of competition by such countries and their national competitors, both in the external and domestic markets, especially where competition is as severe as possible. One such market is a mechanical engineering market.

In the conditions of the development of the postindustrial type of national economies in economically developed countries, where the service industries are becoming increasingly important, mechanical engineering has somewhat lost its importance as a key and strategic sector of the state's economic system. Despite this, it has, however, significant advantages for the economic systems of developing countries, which include: the prevalence of large and medium-sized enterprises, which requires the use of a significant amount of labour and other resources and can increase employment level in the country and reduce unemployment, as well as attract substantial investments, including foreign ones; generating

*Address correspondence to this author at 65058, Odessa, Shevchenko avenue, 10/7, sq.60, Ukraine; Tel: +79617842951; Fax: 8(8793) 39-04-72; E-mail: phdphd509@gmail.com significant volumes of tax and other payments to budgets of different levels; high level of investment in innovation and staff training; significant social activity and solving a number of social problems in the field of operating activities of enterprises; an increase in household income of the country through the purchase of different types of resources from them and the formation of a wide layer of the middle class, which is one of the key problems for countries of this type.

Taking into account the above, one of the important aspects of the development of countries developing their economic systems should be to increase the competitiveness of national mechanical engineering enterprises, expand their range of activities and increase the number of these entities to meet the needs of domestic and foreign markets in the production of mechanical engineering. The above has, however, significant problems in terms of implementation due to insignificant financial capabilities of developing countries and the failure of these countries to invest significant financial resources in the development of mechanical engineering. At the same time, there is a whole group of developing countries that have significant potential for increasing mechanical engineering production and cannot realize it because of a set of problems. These countries include the former countries that were part of the USSR, which have a significant list of mechanical engineering enterprises that gradually become bankrupt and undergo a process of reshaping because of the loss of competition. 
The key problem of the development of mechanical engineering in the developing countries which were part of the USSR is the low efficiency of asset management at the enterprises of this industry. This problem is characteristic for almost all enterprises of the "old regime" that were built in the time of the USSR and privatized at the time of independence and economic reformation of these countries. However, it is at the mechanical engineering enterprises that it is one of the largest and one that has a critical impact on their competitiveness.

This range of problems requires the reform of asset management at mechanical engineering enterprises in the context of increasing their competitiveness in developing countries which have significant potential for the development of mechanical engineering, such as the states that were part of the USSR. It is important here to use the achievements of the scientists to improve the efficiency of the management of competitiveness and assets in enterprises, including mechanical engineering enterprises.

We note active research of the problems of the impact of production and mechanical engineering enterprises on the economic development of countries in the conditions of accelerating globalization processes (De Bernardini 2015; Reinert 2010; Rynn 2011).

Special attention shall be paid to scientific developments on the range of problems in industrial and mechanical engineering in countries that develop their economic systems (Lister and Donaldson 2004; Sami El-Khasawneh 2012; Tybout 2000), including in the states that were part of the USSR (Goncharuk 2007; Krivokon 2016; Saifieva and Yermilina 2008; Tashenov 2013).

We focus on discussion on the role and place of managing competitiveness at modern enterprises (Bondarenko et al. 2018; Gupta, Jain and Dhar 2007; Slavković 2008; Vijeikis and Makštutis 2013; Zelga 2017;), economic entities working in the mechaniocal engineering industry (Boyarynova 2014; Safiullin, Samigullin and Safiullin 2013; Shabaycovitch 2012), including in countries that develop their economic systems (Kuzubov 2016; Zbyrannyk 2016).

We emphasize a significant number of scientific works in the field of asset management in enterprises, including mechanical engineering enterprises, in countries that develop their economic systems. The study of such works by scientists from different countries makes it possible to clearly distinguish between studies in economically developed countries and developing economies, especially in case of the states that were part of the USSR.

Scholars and practicing managers from economically developed countries pay more attention to the practical aspects of asset management at enterprises and the introduction of such management type to improve the efficiency of economic entities. Dwight and El-Akruti (2009) reveal the role of asset management in the success of enterprise strategy. McKeon and Ramshaw (2013) suggest their own point of view on finding the right approach to asset management, the procedure and features of the implementation of asset management in an enterprise. Tikam, Vij and Pal (2016) reveal and describe three main trends of the asset management industry and give advice on their use in the practical work of economic entities.

Scholars from countries developing their economic systems (this, in particular, relates to the states that were part of the USSR as regards studying asset management in enterprises, including mechanical engineering), in their majority, either investigate the theoretical aspects of such management in general (Nagornyi 2014; Vanunts 2004; Zhamoida 2016), or reveal some of its aspects in enterprises of different sectors (Kolesnikov et al. 2016; Lyashchenko and Yukhnovets 2016; Mikheyenko 2014; Vlasova, Smolnyakova and Mikhaylova 2013).

We note that the overwhelming majority of studies by scholars from economically developed countries do not cover the conditions for asset management of mechanical engineering enterprises in developing countries or need to be adapted thereto. At the same time, the scientific developments of scholars from the states that develop their economic systems are mostly narrow and cover either the asset management in a particular country or in a particular industry in the country, or the problems of individual components of the asset management of economic entities. It should also be noted that there is almost no scientific research where asset management is considered as one of the key elements of ensuring or increasing the competitiveness of economic entities, including mechanical engineering enterprises, which should be divided into three large groups: enterprises that are operating as a part of transnational and foreign corporations; large enterprises with a national capital; medium and small economic entities with national 
capital. Therefore, the research emphasizes the necessity of the scientific research, the objective of which is to reveal ways of improving efficiency of asset management in the context of ensuring competitiveness of mechanical engineering enterprises in the countries developing their own economic systems, taking into account the division of such subjects of business entities into three large groups depending on their size and the capital affiliation.

In the study, we consider it appropriate to verify four hypotheses:

- mechanical engineering has a small share of GDP in developing countries and has a negative development dynamics;

- mechanical engineering enterprises from developing countries lose in a competitive struggle to enterprises from developed countries;

- $\quad$ asset management is one of the key elements of impact on the competitiveness of mechanical engineering enterprises in the countries developing their economic systems and has a negative impact on the competitiveness of these enterprises in domestic and foreign markets through a wide range of problems. The last varies depending on facts whether enterprises are the part of transnational or foreign corporations' structure or whether they are large national producers or belong to medium or small business;

- $\quad$ the development and implementation of ways to increase the efficiency of asset management will allow for a sufficient level of competitiveness of mechanical engineering enterprises in developing countries.

\section{MATERIAL AND METHOD}

Data research methods used in this study are the qualitative and quantitive analysis of statistic data on the development and role of mechanical engineering in developing countries with the usage of univariate techniques (UT) based on random sampling. To estimate the competitiveness of mechanical engineering enterprises in developing countries, possibilities of a program package SPSS Statistics have been used. To determine problems of assets management in the context of competitiveness security of mechanical engineering enterprises in the countries developing their own economic systems, the adapted
Metric benchmarking (MB) has been used. It is based on the quantitative analysis with the usage of data envelope analysis (DEA).

The research methodology is based on the historical and systemic approach in disclosing and solving the problems of asset management at the mechanical engineering enterprises in the developing countries as part of ensuring the competitiveness of such enterprises in the domestic and foreign markets.

In this paper, asset management is presented as one of the key elements and key factors affecting the competitiveness of mechanical engineering enterprises in the countries developing their economic systems. The research is also based on the assumption that the asset management problem does not allow to fully realize the competitiveness potential of individual mechical engineering enterprises, the mechanical engineering industry and the economy in developing countries as a whole.

\section{RESULTS}

\subsection{Role and Place of Mechanical Engineering in the Economy of the Developing Countries}

Mechanical engineering plays a particular role and occupies an important place in the economies of the developing countries, which requires a research in this direction. Given the significant number of developing countries in the world, we consider it appropriate to concentrate on four types of countries: countries that were part of the Soviet Union and which have a significant basis for the development of mechanical engineering (Ukraine, Russia, Kazakhstan); countries that became members of the European Union (Poland, Czech Republic); developing countries (Brazil, India); other countries (Egypt, Mexico). Separately, we note the need for research for the period from 2007 to 2018 in the dynamics, which will allow examining the impact of the global economic crisis on the development of mechanical engineering in the countries selected for research.

A key aspect that allows determining the role and place of mechanical engineering in the economy of the country is its ratio to national GDP. As for developing European countries, including those that were part of the USSR (Table 1), we note some very important trends:

- $\quad$ in all countries except Ukraine (-70\%), there was growth in mechanical engineering production 
during the study period, with particularly high indicators in Kazakhstan (50\%) and Czech Republic (57.17);

- $\quad$ in the vast majority of countries, the growth rates of mechanical engineering were faster that GDP growth, with the exception of Ukraine, where growth rates of mechanical engineering were $39.13 \%$ lower than the country's GDP growth rates, and Kazakhstan, where the growth rates of mechanical engineering were $25.24 \%$ lower than the GDP growth rates;

- the overwhelming majority of countries have demonstrated diverse trends in terms of the dynamics of mechanical engineering, where Ukraine has shown a steady decline in the mechanical engineering production volumes, while the Czech Republic is constantly increasing its mechanical engineering production. At the same time, 2013 to 2016 was the period when almost all countries had problems with the development of mechanical engineering;

- $\quad$ the share of mechanical engineering in the GDP of the countries selected for research increased (except for Ukraine and Kazakhstan), but at the end of 2018 it did not exceed 9\% of GDP in any country (Czech Republic - $8.98 \%$ of GDP), accounting for only $1.63 \%$ of GDP in Kazakhstan.

The analysis of the dynamics of GDP and mechanical engineering, as well as the share of mechanical engineering in the GDP of the countries (except Europe) (Table 2) reveals the following trends:

Table 1: Analysis of the Dynamics of GDP and Mechanical Engineering, and the Share of Mechanical Engineering in the GDP of the Developing Countries

\begin{tabular}{|c|c|c|c|c|c|c|c|c|}
\hline \multirow{2}{*}{ Country } & \multicolumn{6}{|c|}{ Years } & \multicolumn{2}{|c|}{ Deviation } \\
\hline & 2007 & 2010 & 2013 & 2016 & 2017 & 2018 & Absolute & Growth rates \\
\hline \multicolumn{9}{|c|}{ Ukraine } \\
\hline GDP, billion USD & 149 & 136 & 180 & 84 & 94 & 103 & -46 & 69.13 \\
\hline $\begin{array}{l}\text { Mechanical Engineering, } \\
\text { billion USD }\end{array}$ & 20 & 19 & 7 & 7 & 6 & 6 & -14 & 30.00 \\
\hline Share in GDP, \% & 13.42 & 13.97 & 3.89 & 8.33 & 6.38 & 5.83 & -7.60 & 43.40 \\
\hline \multicolumn{9}{|c|}{ Russia } \\
\hline GDP, billion USD & 1400 & 1640 & 2300 & 1280 & 1580 & 1580 & 180.00 & 112.86 \\
\hline $\begin{array}{l}\text { Mechanical Engineering, } \\
\text { billion USD }\end{array}$ & 91 & 119 & 95 & 116 & 117 & 120 & 29.00 & 131.87 \\
\hline Share in GDP, \% & 6.50 & 7.26 & 4.13 & 9.06 & 7.41 & 7.59 & 1.09 & 116.85 \\
\hline \multicolumn{9}{|c|}{ Kazakhstan } \\
\hline GDP, billion USD & 105 & 148 & 237 & 137 & 159 & 184 & 79.00 & 175.24 \\
\hline $\begin{array}{l}\text { Mechanical Engineering, } \\
\text { billion USD }\end{array}$ & 2 & 3 & 5 & 2 & 3 & 3 & 1.00 & 150.00 \\
\hline Share in GDP, \% & 1.90 & 2.03 & 2.11 & 1.46 & 1.89 & 1.63 & -0.27 & 85.60 \\
\hline \multicolumn{9}{|c|}{ Poland } \\
\hline GDP, billion USD & 430 & 479 & 524 & 471 & 525 & 550 & 120.00 & 127.91 \\
\hline $\begin{array}{l}\text { Mechanical Engineering, } \\
\text { billion USD ША }\end{array}$ & 24 & 26 & 29 & 28 & 30 & 31 & 7.00 & 129.17 \\
\hline Share in GDP, \% & 5.58 & 5.43 & 5.53 & 5.94 & 5.71 & 5.64 & 0.05 & 100.98 \\
\hline \multicolumn{9}{|c|}{ Czech Republic } \\
\hline GDP, billion USD & 189 & 208 & 209 & 195 & 216 & 245 & 56.00 & 129.63 \\
\hline $\begin{array}{l}\text { Mechanical Engineering, } \\
\text { billion USD }\end{array}$ & 14 & 15 & 15 & 18 & 20 & 22 & 8.00 & 157.14 \\
\hline Share in GDP, \% & 7.41 & 7.21 & 7.18 & 9.23 & 9.26 & 8.98 & 1.57 & 121.22 \\
\hline
\end{tabular}

*- Compiled by the author based on:Committee on Statistics of the Republic of Kazakhstan (2019), Federal Service of State Statistics of the Russian Federation (2019), State Statistics Service of Ukraine (2019), Statistics Poland (2019), The Czech Statistical Office (2019), The International Monetary Fund (2018). 
- $\quad$ growth rates in two of the five selected countries (India, Mexico) were higher than GDP growth rates in the chosen period of study, while in Brazil and especially in Egypt there was a crisis in mechanical engineering;

- $\quad$ among the selected countries, only India has demonstrated a steady increase in production of mechanical engineering products during the study period;

- $\quad$ at the end of 2018 , the share of mechanical engineering did not exceed $7 \%$ of GDP in any of the selected countries (Brazil - $6.23 \%$ of GDP), accounting for only $1.20 \%$ in Egypt.

An important aspect that shows the role and place of the industry in the economy of the country is the share of employed at the enterprises of this industry. We consider it appropriate to carry out research in this direction in the field of mechanical engineering in the countries selected for research (Figure 1).

The research of the share of employed in mechanical engineering in relation to all employed in the selected developing countries indicates a predominantly negative dynamics, with the exception of the Czech Republic $(+0.2 \%$ for the research period), India $(+1.5 \%$ for the research period) and Mexico $(+0,2 \%$ for the research period). Particular attention is paid to the share of employed at mechanical engineering enterprises, which did not exceed $3 \%$ of the employed in the economy $(2.9 \%$ of employed in 2018 in India) in any of the selected countries during the study period. We note significant problems with employment in mechanical engineering in the countries that were part of the USSR, especially in Ukraine, where the share of employed decreased by $1.4 \%$ to $1.1 \%$ of all employed in the country in the research period.

Table 2: Analysis of the Dynamics of GDP and Mechanical Engineering, and the Share of Mechnical Engineering in the GDP of the Developing Countries (Except Europe)

\begin{tabular}{|c|c|c|c|c|c|c|c|c|}
\hline \multirow{2}{*}{ Country } & \multicolumn{6}{|c|}{ Years } & \multicolumn{2}{|c|}{ Deviation } \\
\hline & 2007 & 2010 & 2013 & 2016 & 2017 & 2018 & Absolute & Growth rates \\
\hline \multicolumn{9}{|c|}{ Brazil } \\
\hline GDP, billion USD & 1,400 & 2,210 & 2,470 & 1,790 & 2060 & 1,910 & 510.00 & 136.43 \\
\hline $\begin{array}{c}\text { Mechanical } \\
\text { Engineering, billion } \\
\text { USD }\end{array}$ & 125 & 132 & 135 & 120 & 124 & 119 & -6.00 & 95.20 \\
\hline Share in GDP, \% & 8.93 & 5.97 & 5.47 & 6.70 & 6.02 & 6.23 & -2.70 & 69.78 \\
\hline \multicolumn{9}{|c|}{ India } \\
\hline GDP, billion USD & 1,240 & 1,710 & 1,860 & 2,270 & 2,600 & 2,690 & $1,450.00$ & 216.94 \\
\hline $\begin{array}{c}\text { Mechanical } \\
\text { Engineering, billion } \\
\text { USD }\end{array}$ & 53 & 67 & 80 & 103 & 122 & 129 & 76.00 & 243.40 \\
\hline Share in GDP, \% & 4.27 & 3.92 & 4.30 & 4.54 & 4.69 & 4.80 & 0.52 & 112.20 \\
\hline \multicolumn{9}{|c|}{ Egypt } \\
\hline GDP, billion USD & 137 & 230 & 306 & 333 & 237 & 250 & 113.00 & 182.48 \\
\hline $\begin{array}{c}\text { Mechanical } \\
\text { Engineering, billion } \\
\text { USD }\end{array}$ & 4 & 4 & 4 & 5 & 3 & 3 & -1.00 & 75.00 \\
\hline Share in GDP, \% & 2.92 & 1.74 & 1.31 & 1.50 & 1.27 & 1.20 & -1.72 & 41.10 \\
\hline \multicolumn{9}{|c|}{ Mexico } \\
\hline GDP, billion USD & 1,050 & 1,060 & 1,270 & 1,080 & 1,150 & 1,200 & 150.00 & 114.29 \\
\hline $\begin{array}{c}\text { Mechanical } \\
\text { Engineering, billion } \\
\text { USD }\end{array}$ & 43 & 41 & 44 & 48 & 51 & 53 & 10.00 & 123.26 \\
\hline Share in GDP, \% & 4.10 & 3.87 & 3.46 & 4.44 & 4.43 & 4.42 & 0.32 & 107.85 \\
\hline
\end{tabular}

*- Compiled by the author based on: The International Monetary Fund (2018), World Data Atlas (2019). 


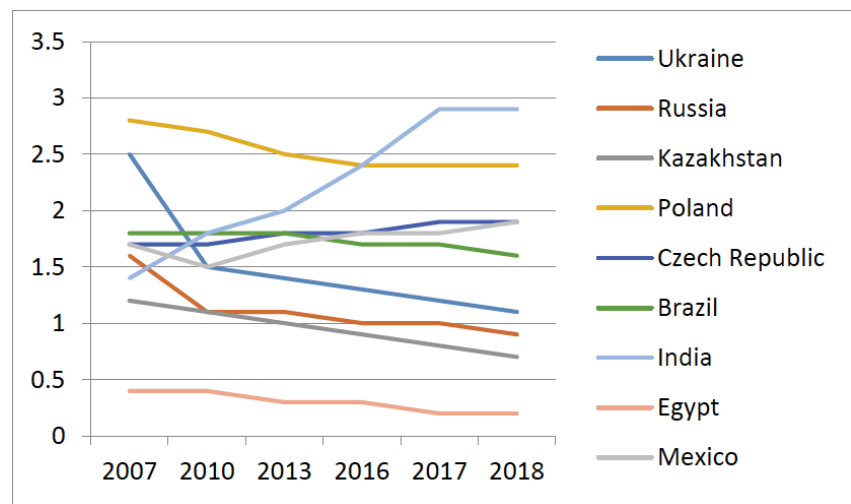

Figure 1: Share of employed in mechanical Engineering to Total Employed in the Developing Countries for 2007-2018.

*- Compiled by the author based on:Committee on Statistics of the Republic of Kazakhstan (2019), Federal Service of State Statistics of the Russian Federation (2019), State Statistics Service of Ukraine (2019), Statistics Poland (2019), The Czech Statistical Office (2019), The International Monetary Fund (2018).

\subsection{Evaluation of Competitiveness of Mechanical Engineering Enterprises in the Devewloping Countries}

Competitiveness is a key characteristic of a modern economic entity, sector of the economy, and the economy of a particular country. It is competitiveness that testifies to the effectiveness of management measures at the micro (enterprise), meso (branch of economy), macro levels (the economy of the country). At the same time, the key factor in ensuring the competitiveness of the enterprise, including mechanical engineering enterprises, is effective asset management (Nagornyi 2014). Taking into account the globalization processes and the involvement of all countries, their branches of economy and individual enterprises in the competitive struggle in the domestic and foreign markets of products (works, services), we consider it appropriate to evaluate the competitiveness of a

Table 3: Analysis of the Share of Mechanical Engineering in the Export and Import of the Developing Countries

\begin{tabular}{|c|c|c|c|c|c|c|c|c|}
\hline \multirow{2}{*}{ Country } & \multicolumn{6}{|c|}{ Years } & \multicolumn{2}{|c|}{ Deviation } \\
\hline & 2007 & 2010 & 2013 & 2016 & 2017 & 2018 & Absolute & Growth rates \\
\hline \multicolumn{9}{|c|}{ Ukraine } \\
\hline Share in exports, \% & 10,1 & 11,0 & 11,0 & 10,0 & 9,9 & 9,9 & $-0,2$ & 98,02 \\
\hline Share in imports, \% & 17,4 & 13,4 & 15,6 & 20,1 & 20,0 & 20,8 & 3,4 & 119,54 \\
\hline \multicolumn{9}{|c|}{ Russia } \\
\hline Share in exports, \% & 5,1 & 4,3 & 4,6 & 4,9 & 6,0 & 6,1 & 1 & 119,61 \\
\hline Share in imports, \% & 54,3 & 47,0 & 46,4 & 44,6 & 45,6 & 45,3 & -9 & 83,43 \\
\hline \multicolumn{9}{|c|}{ Kazakhstan } \\
\hline Share in GDP, \% & 1,7 & 1,7 & 1,5 & 1,4 & 1,4 & 1,1 & $-0,6$ & 64,71 \\
\hline Share in GDP, \% & 38,6 & 39,2 & 40,0 & 39,2 & 37,2 & 40,3 & 1,7 & 104,40 \\
\hline \multicolumn{9}{|c|}{ Poland } \\
\hline Share in GDP, \% & 28,5 & 43,1 & 39,3 & 40,6 & 43,5 & 44,1 & 15,6 & 154,74 \\
\hline Share in GDP, \% & 30,2 & 35,5 & 36,2 & 39,0 & 30,3 & 34,4 & 4,2 & 113,91 \\
\hline \multicolumn{9}{|c|}{ Czech Republic } \\
\hline Share in GDP, \% & 40,5 & 49,6 & 38,7 & 33,4 & 33,0 & 33,3 & $-7,2$ & 82,22 \\
\hline Share in GDP, \% & 41,0 & 43,2 & 35,8 & 30,3 & 29,8 & 30,1 & $-10,9$ & 73,41 \\
\hline \multicolumn{9}{|c|}{ Brazil } \\
\hline Share in GDP, \% & 18,5 & 16,1 & 15,3 & 11,9 & 12,4 & 13,5 & -5 & 72,97 \\
\hline Share in GDP, \% & 39,2 & 36,4 & 28,8 & 34,3 & 34,9 & 32,7 & $-6,5$ & 83,42 \\
\hline \multicolumn{9}{|c|}{ India } \\
\hline Share in GDP, \% & 10,6 & 11,7 & 11,5 & 12,0 & 12,1 & 12,6 & 2 & 118,87 \\
\hline Share in GDP, \% & 16,3 & 15,3 & 11,2 & 11,5 & 10,9 & 11,1 & $-5,2$ & 68,10 \\
\hline \multicolumn{9}{|c|}{ Egypt } \\
\hline Share in GDP, \% & 2,2 & 5,1 & 5,6 & 6,1 & 6,3 & 6,1 & 3,9 & 277,27 \\
\hline Share in GDP, \% & 6,1 & 8,6 & 8,0 & 8,4 & 8,7 & 8,0 & 1,9 & 131,15 \\
\hline \multicolumn{9}{|c|}{ Mexico } \\
\hline Share in GDP, \% & 16,5 & 17,4 & 17,5 & 18,0 & 19,0 & 18,8 & 2,3 & 113,94 \\
\hline Share in GDP, \% & 16,7 & 17,4 & 17,3 & 17,7 & 17,6 & 17,1 & 0,4 & 102,40 \\
\hline
\end{tabular}

*- Compiled by the author based on: World Data Atlas (2019). 
particular industry (it is mechanical engineering in our case) to investigate the dynamics and to compare the share of production of this industry in the total exports and imports of the country (Table 3 ).

It is worth noting that the high share of exports of mechanical engineering products in the country's exports of goods indicates high competitiveness in international markets and vice versa, while the high share of imports of mechanical engineering products in the total imports of goods of the country indicates a loss of domestic manufacturers of mechanical engineering products to foreign manufacturers in the national market and vice versa. The situation when there is a high share of exports of mechanical engineering products with a high share of imports of mechanical engineering products mainly indicates the narrow specialization of the mechanical engineering complex in the country, which provides its competitiveness in the foreign and national markets, other segments of mechanical engineering are either not developed, or lose competitive struggle in domestic and foreign markets. The situation is also possible when the share of exports of mechanical engineering products is insignificant in the total exports of the country with insignificant share of imports in the total imports of the country which can testify either about a high degree of closing of the national mechanical engineering market from foreign suppliers, or about the tangible decline of the capacity of the national mechanical engineering market against the backdrop of crisis manifestations in the economy of the country with low competitiveness of domestic mechanical engineering enterprises in foreign markets.

Evaluation of the competitiveness of the mechanical engineering enterprises in the developing countries selected for the study showed (Table 3 ) the multidirectional trends in the competitiveness of mechanical engineering in these countries, where, against the background of quite successful countries such as Poland, the Czech Republic, there are countries with insignificant (India, Mexico) and critical (Ukraine, Russia, Kazakhstan, Brazil, Egypt) problems of the competitiveness of national mechanical engineering enterprises. Particular attention shall be paid to the problems of ensuring the competitiveness of mechanical engineering in Ukraine, Russia and Kazakhstan, which have a significant number of relevant enterprises and high potential for increasing mechanical engineering production, based on what was achieved at the time of operation as part of the industrial complex of the USSR.

\subsection{Issues of Asset Management in the Context of Ensuring the Competitiveness of Mechanical Engineering Enterprises in the Developing Countries}

Conducted evaluation of the competitiveness of the mechanical engineering industry in developing countries suggests a predominantly insufficient level of competitiveness of enterprises producing mechanical engineering products in the countries selected for research. At the same time, a significant number of scholars (Boyarynova 2014; McKeon and Ramshaw 2013; Nagornyi 2014) emphasize the key importance of asset management in the context of ensuring the competitiveness of enterprises, including mechanical engineering enterprises. We note that the main aspects of ensuring the competitiveness of an economic entity are directly related to the management of its assets (Figure 2).

Thus, we can point out that the low competitiveness of engineering enterprises in developing countries is caused by problems in managing the assets of these enterprises. It is clear that the problems of managing assets in different countries differ somewhat (national specifics of problems), they also differ for different types of mechanical engineering enterprises (type problem specifics) and individual enterprises of this industry (individual problem specifics). Thus, the problems of mechanical engineering enterprises that are part of large transnational and foreign corporations are significantly different from the problems of national manufacturers, and the problems of large enterprises are not identical to the problems of small and mediumsized enterprises, which needs to be adequately detailed in the study.

Within the framework of the effective localization of the aggregate of asset management problems in the context of ensuring the competitiveness of mechanical engineering enterprises in the developing countries, we divide them into subgroups, namely:

1. Problems of asset management of mechanical engineering enterprises from the developing countries, which are part of transnational and foreign corporations.

2. Problems of asset management of large national manufacturers of mechanical engineering products from the developing countries.

3. Problems of asset management of medium and small mechanical engineering enterprises from the developing countries. 


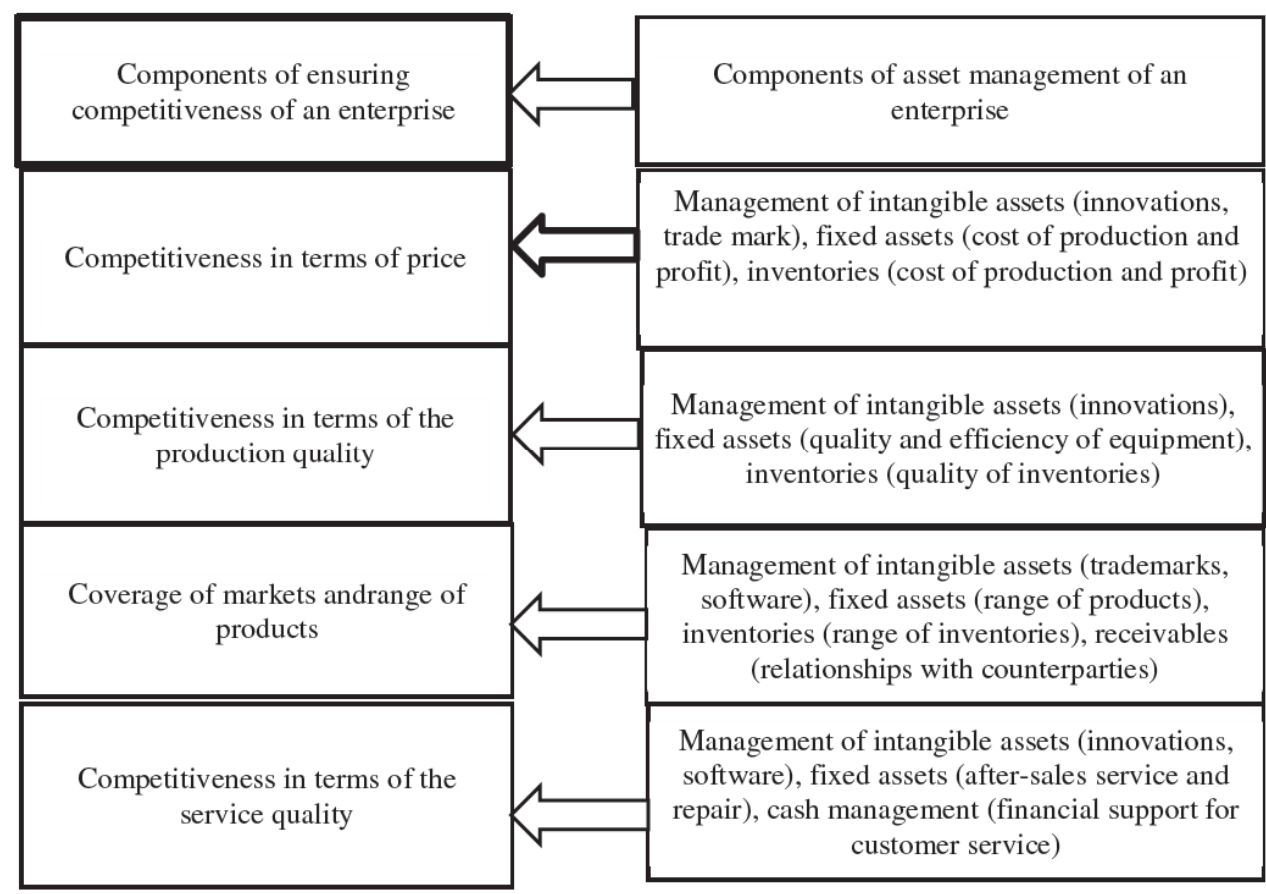

Figure 2: Interrelation of the Competitiveness of Enterprises with Asset Management.

Source: developed by the author.

At the same time, we consider it inappropriate to provide the national specifics of problems and individual issues of enterprises in the research paper based on the purpose and scope (this direction requires separate research).

The problems of asset management of mechanical engineering enterprises from the developing countries that are part of transnational and foreign corporations include: a narrow range of development and implementation of innovations (a significant number of enterprises carries out operational activities in order to prolong the life cycle of obsolete products and technologies); critical limitation of autonomy in asset management (investment in intangible and tangible assets, fixed assets, interaction with debtors, investment and innovation activities); strict subordination of the development strategy of a transnational or foreign corporation; difficulties of the development of trademarks and their reaching national markets; significant timeframes for decision making, low flexibility and adaptability to changing conditions of economic activity.

Problems in the asset management of large national manufacturers of mechanical engineering products from developing countries are as follows: difficult access to international capital markets; limited investment resources to improve the quality of fixed assets and intangible assets; low innovation activity; predominant emphasis on price competition; complexity of development and marketing of trade marks, especially in the international and world market of mechanical engineering products; complexity of adaptation to national requirements when entering new markets; high levels of corruption, especially in the supply and distribution departments; miscalculations in developing a strategy for enterprise development, as well as asset management strategies and their individual components.

Medium and small mechanical engineering enterprises from the developing countries have the largest number of asset management problems, where specific problems of the relevant enterprises from the countries selected for research are added to the general problems of this type of economic entities. Here we emphasize the following issues:

almost complete absence of innovations and an emphasis on copying the experience and developments of the leading mechanical engineering enterprises. In Ukraine, only $10 \%$ of small and medium-sized mechanical engineering enterprises carry out innovative developments or sell innovative products (State Statistics Service of Ukraine 2019);

- $\quad$ lack of trademarks or low level of their support and introduction to the markets of products; 
the use of non-licensed software. In the Russian Federation, the share of such software used by small and medium-sized mechanical engineering enterprises at the end of 2018 amounted to $82 \%$ (Federal Service of State Statistics of the Russian Federation 2019), and in Brazil - 73\% (World Data Atlas 2019);

critical depreciation of fixed assets and insufficient rates of their recovery. Thus, the depreciation of fixed assets in small and medium-sized mechanical engineering enterprises in Ukraine, the Russian Federation and Kazakhstan at the end of 2018 ranged from 64 to $96 \%$ (Committee on Statistics of the Republic of Kazakhstan 2019; Federal Service of State Statistics of the Russian Federation 2019; State Statistics Service of Ukraine 2019);

high levels of receivables of both state structures regarding the administration of taxes and fees, and economic entities in relation to the purchase of products of enterprises and the supply of raw materials, materials, semi-finished products to these enterprises;

the critical low quality of inventory management, which leads either to idle production due to a shortage of raw materials, materials, semifinished products, or due to over-loading of warehouses with finished products. We also note another situation: some enterprises have excessive production inventories, which has a negative impact on the cost of production and the rate of profit;

low efficiency of current assets management (stocks, accounts receivable, cash), which leads to permanently emerging crises of cash deficiency, or its excessive amounts in the accounts of enterprises;

almost complete lack of strategic asset management and planning due to the lack of trained staff, making managerial staff busy with current activities, lack of understanding by owners and top managers of enterprises of the importance of such management activities;

the predominance of intuitive management instead of a scientific approach to its implementation due to the lack of training of owners and top managers of economic entities; critical level of corruption and informal relationships in management due to the poor quality of recruitment, especially for middle and senior managers.

The revealed range of asset management problems suggests the need to increase the efficiency of this type of management in mechanical engineering enterprises in the countries that develop their economic system. In this case, the efficiency shall be understood as the ability to achieve something with the least resources (Dictionary 2019). In case of asset management, we can talk about achieving such a level of competitiveness, which will provide a sufficient rate of profitability of the enterprise in the long run.

However, increasing the efficiency of asset management at mechanical engineering enterprises in the developing countries requires the development and implementation of appropriate ways to include:

1. Implementation of foreign experience in asset management, both from the point of view of theoretical and practical developments in this area of management, since, in modern conditions, mechanical engineering enterprises from the developing countries are trying to eliminate problems, most of which are localized and eliminated in economically developed countries.

2. A scientific approach to asset management, based on raising the level and quality of training and retraining of owners, managers and staff (especially senior and middle managers) with the maximum possible deviation from the practice of intuitive decision-making in this managerial field.

3. Increased focus on managing intangible assets with an emphasis on innovation activity and eliminating the practice of using non-licensed software.

4. Activation of fixed assets management with an emphasis on accelerating their recovery and finding ways to obtain additional resources for the renovation of this component of assets of mechanical engineering enterprises.

5. Improving the quality of inventory management based on the principles of: sufficiency, elimination of excessive, relevance, timeliness, reduction of excessive resource consumption for maintenance, automation of management 
processes, innovation, reducing unproductive costs.

6. Enhancing the quality of management of accounts receivable in order to increase the level of return on its use for the enterprise and reducing the amounts and periods of withdrawal from the economic circulation of funds of economic entities in the mechanical engineering industry.

7. Formation of an updated approach to cash management of an enterprise in order to reduce their unproductive use within the scope of economic activity, as well as obtaining additional sources of profit.

\section{DISCUSSION}

Problems of reducing disparities in the development of economically developed countries and countries that only develop their economic systems are among the most important in the current conditions of the global economy. At the same time, the key aspect here is to increase the competitiveness of the economies of developing countries, individual sectors, as well as enterprises (Reinert 2010; Sami El-Khasawneh 2012). It is rather important in this direction to investigate the competitiveness of mechanical engineering enterprises in such countries, identify problems and propose ways to eliminate them.

We note that the hypothesis that was put forward at the beginning of the study, according to which mechanical engineering occupies a small part of GDP in the developing countries and has a negative development dynamics, has not fully confirmed. In case of the selected countries, only in Egypt we can talk about the insignificant volumes of mechanical engineering in the country's GDP. In relation to other countries, one can speak of the average and significant influence of mechanical engineering industry on the formation of GDP. An analysis of the dynamics of mechanical engineering in the countries selected for research indicates that it has grown in the vast majority, at the same time faster than the GDP of these countries, except for countries that, in the course of the research, had crisis manifestations in their economy (Ukraine, Brazil). It should be noted separately that crises have a critical negative effect on the development of mechanical engineering in the country, causing a decrease in the industry to a greater extent than the GDP of the country as a whole. At the same time, we note the decline in the number of employed in mechanical engineering in the vast majority of countries selected for research, which is a very significant problem for countries in which there is a high share of the unemployed in the total able-bodied population (excluding Poland, Czech Republic).

The hypothesis according to which the mechanical engineering enterprises from developing countries are losing the competitive struggle to the enterprises from the developed countries has only partially been confirmed. There is no loss in the countries where the vast majority of the mechanical engineering complex is multinational and foreign corporations (Czech Republic, Poland, Mexico); in countries where the vast majority of mechanical engineering enterprises have national capital (Ukraine, Russia, Kazakhstan, Egypt) the hypothesis has been confirmed. The exception is Brazil, where the vast majority of mechanical engineering companies are part of transnational and foreign corporations, and India, where a significant share of mechanical engineering has a national ownership of capital.

The hypothesis that asset management is one of the key elements of the impact on the competitiveness of mechanical engineering enterprises in countries developing their economic systems and has a negative impact on the competitiveness of these enterprises in the domestic and foreign markets, due to the wide range of problems, has, to a large extent, been confirmed, although the problems of such enterprises are very different, based on whether they belong to transnational or foreign corporations, are large national production manufacturers or belong to the middle or small business. In this context, the study has common features with the research conducted by Zhamoida (2016) regarding coal mining enterprises of Ukraine and Nagornyi (2014) concerning the study of asset management of the enterprise in relation to its competitiveness. A significant constraint within this aspect of the study is the complexity of summarizing the results of analyzing the problems of individual mechanical engineering enterprises in the developing countries.

The hypothesis, based on the assertion that the development and implementation of ways to increase the efficiency of asset management will allow for sufficient level of competitiveness of mechanical engineering enterprises in the developing countries, has been fully confirmed. 
The key value of the research paper is an attempt to reveal the relationship between the competitiveness of mechanical engineering enterprises in the developing countries and the assets management in these enterprises, and to relate the problems of such management and the ways of their solution with the increase of competitiveness of economic entities manufacturing mechanical engineering products. In this regard, some limitations can be distinguished in applying the results of this research paper, namely: the complexity of the analysis for all developing countries, which requires their substantiated classification; the need to take into account the individual problems of mechanical engineering enterprises, which requires application of methods of economical and mathematical modelling; the need to further detailing of the ways to increase the efficiency of asset management at mechanical engineering enterprises in the countries developing their economic systems. At the same time, the formulated restrictions do not reduce the scientific and practical value of this research paper and characterize the prospects for further research.

\section{CONCLUSION}

Mechanical engineering has a significant potential for a positive impact on the economies of the developing countries. Taking into account its share in GDP and the number of people employed, as well as the growth rates in the overwhelming majority of the countries developing their economic systems, we emphasize its importance to ensure their sustainable economic growth. At the same time, the problems of ensuring the competitiveness of mechanical engineering enterprises in the developing countries are becoming one of the key constraints on the reduction of disparities between these countries and economically developed countries. In this context, asset management, localization and elimination of such management problems in mechanical engineering enterprises in the countries that develop their economic systems are basic.

The proposed classification and the identified set of problems, as well as ways to eliminate them in the field of asset management will allow the mechanical engineering of the developing countries to increase their competitiveness in the domestic and foreign markets and positively affect the competitiveness of both industry and the economies of such countries within the global economic system.
The practical implementation of the proposals and conclusions of this research paper should be considered in the context of their importance for increasing the competitiveness of individual mechanical engineering enterprises, mechanical engineering industry, industry in general and national economies in the developing countries.

The prospects for further research on the basis and using the scientific results of this study are in detailing: the links between competitiveness and asset management at the mechanical engineering enterprises in the developing countries; developing ways to increase the efficiency of asset management in the context of increasing the competitiveness of such enterprises.

\section{REFERENCES}

Bondarenko, Svitlana, IrynaLiganenko, Olga Kalaman, and LiubovNiekrasova.2018. "Comparison of Methods for Determining the Competitiveness of Enterprises to Determine Market Strategy." International Journal of Civil Engineering and Technology 9(13): 890-898.

Boyarynova, Kateryna O. 2014. "Foreign Experience of Using Innovation Oriented Methods of Ensuring Competitiveness of Engineering Enterprises."Economics and organization of management 3-4: 30-37.

Committee on Statistics of the Republic of Kazakhstan.(2019). Statistical Information, Industry. Retrieved May 18, 2019 (http://stat.gov.kz/faces/wcnav externalld/homeNumbersIndu stry?_afrLoop $=1016268814548538 \# \% 40 \% 3 \mathrm{~F}$ afrLoop\%3D1 016268814548538\%26_adf.ctrl-state\%3D8b76̄94jrs_58)

De Bernardini, Luigi. 2015. The Role of Manufacturing in Economic Development. Retrieved May 18, 2019 (https://www. automationworld.com/role-manufacturing-economicdevelopment)

Dictionary.(2019). Efficiency. Retrieved May 18, 2019 (https://www. dictionary.com/browse/efficiency)

Dwight, Richard A. and Khaled O.El-Akruti.2009. The Role of Asset Management in Enterprise Strategy Success. 13th annual ICOMS, Asset Management Conference.Informit, pp. 68-76.

Federal Service of State Statistics of the Russian Federation.(2019). Statistical Information, Industrial production.Retrieved May 18, 2019 (http://www.gks.ru/wps/wcm/connect/rosstat_main/ rosstat/ru/statistics/enterprise/industrial/\#)

Goncharuk, Anatoliy G. 2007. "Impact of Political Changes on Industrial Efficiency: A Case of Ukraine." Journal of Economic Studies 34(4): 324-340. https://doi.org/10.1108/01443580710817443

Gupta, Prashant, Rajesh Jain, and UpinderDhar. 2007. Enhancing Enterprise Competitiveness (Marketing, People, IT and Entrepreneurship). New Delhi: Allied Publishers.

Kolesnikov, Olexii, Viktor Gogunskii, KaterynaKolesnikova, DmytroLukianov, and TetianaOlekh.2016. "Development of the Model of Interaction among the Project, Team of Project and Project Environment in Project System."EasternEuropean Journal of Enterprise Technologies 9/83: 20-26. https://doi.org/10.15587/1729-4061.2016.80769

Krivokon, Maryna. O. 2016. "Mechanical Engineering in Ukraine: The State, Dynamics and Prospects with Using Effective Concepts of Crisis Management."Intelekt XXI 5: 182-186. 
Kuzubov, Aleksey A. 2016."Machine-building Enterprises Competitiveness as an Object of Strategic Management."The bulletin of the Far Eastern Federal University. Economics and Management 1(77): 71-76.

Lister, G., and K. Donaldson. 2004."New Roles for Industrial Engineers in Developing Countries."South African Journal of Industrial Engineering 15(1): 43-52. https://doi.org/10.7166/15-1-237

Lyashenko, Natalya A., and Liana Y. Yukhnovets.2016. "Some Issues of Efficiency in Using Enterprise Current Assets."Upravlenieiekonomika v XXI veke 1: 13-18.

McKeon, Paul, and DarrenRamshaw.2013. Implementing Enterprise Asset Management for Dummies. Chichester: John Wiley \& Sons, Ltd.

Mikheyenko, Ekaterina S. 2014. "Management of Intangible Assets as a Component of a Strategy to Improve a Company's Capitalization."Business inform. Section: Economics of Enterprise 6: 237-241.

Nagornyi, Evgen I. 2014."Assets Management System as a Relevant Factor of Effective Enterprise's Development."Economical science. Seria "Economics and Management" 11: 223-233.

Reinert, Erik. 2010. How Rich Countries Got Rich and Why Poor Countries Stay Poor. Constable: London.

Rynn, Jon. 2011. Six Reasons Manufacturing is Central to the Economy. Retrieved May 18, 2019 (http://rooseveltinstitute. org/six-reasons-manufacturing-central-economy)

Safiullin, Marat R., IInur G. Samigullin, and Lenar N. Safiullin. 2013. "Model of Management of Competitiveness of a Machinebuilding Complex."World Applied Sciences Journal 27(13): 212-216.

Saifieva, S. N., and D. A. Ermilina.2008. "Problems of Development of Russian Engineering." Pp. 153-55 in Abstracts of the report at the Ninth All-Russian Symposium: Strategic Planning and Development of Enterprises. Moscow: CEMI RAS.

Sami El-Khasawneh, Bashar. 2012. "Challenges and Remedies of Manufacturing Enterprises in Developing Countries: Jordan as a Case Study."Journal of Manufacturing Technology Management 23(3): 328-350. https://doi.org/10.1108/17410381211217407

Shabaycovitch, Victor. 2012. "Competitiveness of Products, Equipment and Technological Processes in MachineBuilding."Advances in manufacturing science and technology 36(1): 74-81. https://doi.org/10.2478/v10264-012-0007-2

Slavković, Marko. 2008. "Strengthening Enterprises Competitiveness Through Development of Knowledge Management Concept."FactaUniversitatis, Series: Economics and Organization 5(2): 167-172.

State Statistics Service of Ukraine. 2019. Statistical information. Retrieved May 18, 2019 (http://www.ukrstat.gov.ua)
Statistics Poland.(2019). Statistical yearbooks. Retrieved May 18, 2019 (http://stat.gov.pl/obszary-tematyczne/rocznikistatystyczne)

Tashenov, Ardak. 2013. "Kazakhstani Machine Building: Challenges and Growth Prospects."Kazakhstan International Business Magazine1.Retrieved May 18, 2019 (http://www.investkz. com/journals/88/1057.html)

The Czech Statistical Office.2019. Industry, Energy. Retrieved May 18, 2019 (https://www.czso.cz/csu/czso/industry_ energy_ekon)

The International Monetary Fund. 2018. GDP, Current Prices. Retrieved May 18, 2019 (https://www.imf.org/external/ datamapper/NGDPD@WEO/OEMDC/ADVEC/WEOWORLD)

Tikam, Jay, AmitVij, and Neelesh Pal. 2016.Three Trends Shaping the Asset Management Industry, and How to Capitalise on Them.Retrieved May 18, 2019 (http://www.wns.com/Portals/ 0/Documents/Whitepapers/PDFFiles/651/34/WNS_Whitepap er_Three_Trends_Shaping_the_Asset_Management_Industr y_and_How_to_Capitalise_on_Them.pdf)

Tybout, James R. 2000. "Manufacturing Firms in Developing Countries: How Well Do They Do, and Why?"Journal of Economic Literature 38(1): 11-44. https://doi.org/10.1257/jel.38.1.11

Vanunts, R. V. 2004. "Analysis of Factors for Improving the Asset Management Efficiency of a Machine-Building Enterprise."Property Relations in the Russian Federation 5(32): 32-36.

Vijeikis, Juozas, and AntanasMakštutis.2013. The Factors of Competitiveness at Management Levels in the Context of Globalization. Retrieved May 18, 2019 (http://du.lv/wpcontent/uploads/2013/10/8Vijeikis.pdf)

Vlasova, Nataliya O., Nataliya M. Smolnyakova, and Olena V. Mikhaylova,2013."Principles and Main Stages of Optimisation in the System of Management of Circulating Assets in Retail Trade Companies."Business inform. Section: Economics of Trade and Services 6: 202-208.

World Data Atlas.2019. World and Regional Statistics, National Data, Maps, Rankings. Retrieved May 18, 2019 (https://knoema.com/atlas?origin=knoema.ru\&_ga $=2.266480$ 654.124507922.1549790470-1687744396.1549790470)

Zbyrannyk, Oksana. 2016. "The Formation of the Competitiveness of the Enterprises of Machine-Building Complex of Ukraine."Baltic Journal of Economic Studies 2(4): 35-40. https://doi.org/10.30525/2256-0742/2016-2-4-35-40

Zelga, Kamila. 2017. "The Importance of Competition and Enterprise Competitiveness."World Scientific News 72: 301-306.

Zhamoida, Oleksii. 2016. "Managing Mining Enterprises' Assets as the Basis of Their Competitiveness." Mining of Mineral Deposits 10(4): 50-55. https://doi.org/10.15407/mining10.04.050

\section{DOI: https://doi.org/10.6000/1929-7092.2019.08.73}

(C) 2019 Irina M. Yepifanova; Licensee Lifescience Global.

This is an open access article licensed under the terms of the Creative Commons Attribution Non-Commercial License (http://creativecommons.org/licenses/by-nc/3.0/) which permits unrestricted, non-commercial use, distribution and reproduction in any medium, provided the work is properly cited. 